\title{
Evaluation of Radish (Raphanus sativus L.) Varieties Under Shade-net Condition for Yield and Quality
}

\author{
Kumar Mani Dahal $^{*}$, Dhruba Raj Bhattarai ${ }^{1}$, Moha Dutta Sharma ${ }^{2}$, Bishwash Poudel ${ }^{1}$ \\ ${ }^{I}$ Nepal Agricultural Research Council, National Outreach Research Centre, Khumaltar, Lalitpur, \\ ${ }^{2}$ Agriculture and Forestry University, Department of Horticulture, Rampur, Chitwan, Nepal \\ "Corresponding Author's Email: kumarmanidahal@gmail.com \\ "Orcid ID: https://orcid.org/0000-0003-0291-946X
}

Received on:11 September 202, Revised on: 6 January 2021, Accepted on: 22 March

\begin{abstract}
This experiment was carried out in a shade net house at the horticultural research farm of Agriculture and Forestry University, Chitwan, Nepal during spring 2018to identify the suitable radish (Raphanus sativus L.) variety having high yield potential with better quality roots for off season. The experiment was laid out in Randomized Complete Block Design (RCBD) with eight treatments, i.e. five improved (Vedetar Local, Miyasinge, Tokinasi, Pusa Chetki and All Season) and three hybrid varieties (Mino Early Long White F1, Ivory White F1 and MAHY 22 F1) of radish with four replications.Radish seeds were seeded in the third week of February. Miyasingevariety showed the highest plant height $(43.91 \mathrm{~cm})$, biomass yield $\left(73.22 \mathrm{tha}^{-1}\right)$ and fresh shoot weight per plant (127.15 g)whereasthehighest number of leaves per plant (20.54) was recordedinMAHY $22 \mathrm{~F} 1$. Ivory White F1 variety showed thehighest root length $(19.51 \mathrm{~cm})$, root circumference $(9.31 \mathrm{~cm})$, root to shoot ratio per plant (1.29) and fresh root yield $\left(30.87 \mathrm{t} \mathrm{ha}^{-1}\right)$. The highest root skin thickness $(0.27 \mathrm{~cm})$ was found in Miyasinge,the highest TSS (6.20 ${ }^{\circ}$ Brix) was observed in Mino Early Long White F1. Ivory White F1 showed the highest ascorbic acid content $\left(19.51 \mathrm{mg} 100 \mathrm{~g} \mathrm{~g}^{-1}\right)$,dry matter of root (7.62\%) and score (8.36) from the consumers' acceptability test for pungency. Ivory White F1 showed superior growth, yield and quality attributesunder shed net conditions.
\end{abstract}

Keywords: Bolting,Cultivation, Off-season, Production, Temperature

\section{Introduction:}

Radish (Raphanus sativus L.) is an important nutritious, quick growing and short duration root vegetable crop grown all over the world (Lavanya et al., 2014). It is a herbaceous annual or biennial plant which belongs to Brassicaceae family (Chandel et al.,2015).The young tender fresh root is sweet or pungent in taste, consumed either as a salad or cooked (Hamouda et al., 2014). Fresh leaves and root are a rich source of vitamin A and C, other minerals (Jilaniet et al.,2010) and antioxidant (Noreen \&Ashraf, 2009). It is a suitable crop for both open field and protected cultivation for year round supply (Mishra et al.,2010).

Radish is sensitive to temperature requirement; in general, it is adapted to a cool or moderate climate. In Terai of Nepal radish is grownfrom September to January as a winter season root vegetable crop (NARC, 2017). But some Asian varieties resist more temperature as compared to European varieties. The temperature range from $20-23^{\circ} \mathrm{C}$ promotes higher nutrient uptake and dry matter content (Nieuwhof, 1978). The water requirementof the crop increases and root may be 
deformed when the temperature increases higher than $25-30^{\circ} \mathrm{C}$. Similarly, long day with the hot weather results in early bolting before proper development of the root,making ithard, pithy and pungency is developed before maturity (Selvakumar et al, 2019). The pungency in radish is due to the presence of volatile isothiocyanate (trans- 4-methylthiobrate) which is considered to be an appetizer (Thoratet al.,2015).

It is a high demand salad vegetable crop throughout the year in the urban and cities due to changes in food habit of the people and massivelyincreased urbanization. Demand and supply trend of vegetables is ashift from quantity to quality(Teyet al.,2009).Its trend is not only to obtain higher yield but also to maximize the quality of the produce as produce gets premium price. There are a number of factors like variety, growing environment and season, availabilities of irrigation and nutrition, disease and insect pest infestation etc. which play key role in quantity as well as quality production (Politud, 2016, NARC, 2017). The most important quality characteristics of root vegetables for fresh market are root shape and size,uniformity, color, texture and sensory quality (Larsen \&Wold, 2016). In Nepal, area under radish production is 18,250 hectares and total production is 287,200 metric ton with average production of 15.74 metric ton per hectares. In Chitwan district, radish is cultivated in an area of 190 hectares with total production of 2985 metric ton and productivity $15.71 \mathrm{t} / \mathrm{h}$ (MoALD, 2020).

There are several open pollinated and hybrid radish variety seeds available in the market, having different varietal characters such as root color, taste, length, size, yield potential and quality parameters. The growers are searchingfor the high yielding and varieties having good qualities every year.Farmers buy radish seed according to the information provided by the seed traders. The productivity and quality of these different varieties are not yet tested scientifically. This research focused on the selection of superior radish variety having high yield potential with better quality roots for off season (spring season) production under the shed net for plane areas of Chitwan, Nepal.

\section{Materials and Methods:}

A field study was conducted at the horticulture research farm of Agriculture and Forestry University Rampur, Chitwan, Nepal, during the mid of February to mid of April, 2018 for evaluation of radish (Raphanus sativus L.) varieties for yield and quality attributes under shade net. This experiment was laid out in a Randomized Complete Block Design (RCBD) with eight treatments and four replication. Eight varieties of radish including, five improved varieties (viz. Vedetar Local, Miyasinge, Tokinasi, Pusa Chetki, All Season) and three hybrid varieties (viz. Mino Early Long White F1, Ivory White F1 and MAHY 22 F1) were evaluated. Individualplot size of $1.5 \mathrm{~m}^{2}(1.5 \mathrm{~m} \times 1 \mathrm{~m})$ were used. Each plot comprised of 50 plants (5 rows a plot and 10 plants a row). Two net houses of size $8 \mathrm{~m} \times 5 \mathrm{~m} \times 2 \mathrm{~m}$ were used in such a way that each net house contained 2 replications. Each replication (block) accommodated 8 plots arranged in two columns of 4 plot each. The spacing of $0.25 \mathrm{~m}$ was kept between plots and $0.50 \mathrm{~m}$ between replications. Commercially availablegreen coloured $50 \%$ shade net was used as cladding materials and 30 mesh size insect net was used as side cover. All the varieties were randomized separately in each replication.The well decomposed Farm Yard Manure (FYM) at the rate of $20 \mathrm{tha}^{-1}$, Diammonium Phosphate (DAP) $108 \mathrm{~kg} \mathrm{ha}^{-1}$, Muriate of Potash (MOP) $83 \mathrm{~kg} \mathrm{ha-}$ ${ }^{1}$, half of Urea $85 \mathrm{~kg} \mathrm{ha}^{-1}$ and Borax $10 \mathrm{~kg}$. ha- ${ }^{-1}$ were applied as basal dose. The remaining half dose of Urea $85 \mathrm{~kg} \mathrm{ha}^{-1}$ was applied as topdressing in two equal split doses on 20 and 35 days after sowing (DAS). Irrigation was provided at regular interval and the field was kept free from weeds manually. The seeds were sown on line at a depth of $1.5 \mathrm{~cm}$. and spacing between rows and plants was maintained at 20 and $15 \mathrm{~cm}$, respectively. Thinning was done at 15 DAS by retaining one seedling per hill. The observations were recorded from ten randomly selected plants from the center of the plotdiscarding one row from both sides and two plants at each fronts. Observations were made on quantitative as well as qualitative traits such as: Plant height $(\mathrm{cm})$, Number of leaves per plant, Shoot weight per plant (g), Rootlength $(\mathrm{cm})$, Root circumference $(\mathrm{cm})$, Root to shootratio, Total biomass yield $t \mathrm{ha}^{-1}$, Root yield $\mathrm{t} \mathrm{ha}^{-1}$, Skin thickness $(\mathrm{cm})$, Total soluble solids (TSS) of root $\left({ }^{\circ}\right.$ Brix) and Ascorbic acid (mg $\left.100 \mathrm{~g}^{-1}\right)$, Dry matter (\%) of the roots and Consumer acceptability test. Yield $(\mathrm{t}$ $\mathrm{ha}^{-1}$ ) was calculated on net plot basis. The data obtained from selected plants were used to analysis of variance at $5 \%$ level of significance by using Statistical Tools for Agricultural Research (STAR), version: 2.0.1, 2014 edition developed by International Rice Research Institute (IRRI). 


\section{Result:}

\section{Growth parameters}

There was significant difference in average growth parameters of different varietiesat the time of harvest (Table 1). The highest Plant height $(43.91 \mathrm{~cm})$ was recorded in Miyasinge and followed by Tokinasi (43.69 $\mathrm{cm})$. The lowest Plant height was recorded in Pusa Chetki $(37.08 \mathrm{~cm})$.
Furthermore, the highest Number of leaves per plant was produced by MAHY 22 F1 (20.54) followed by Vedetar Local (20.25). The lowest Number of leaves per plant was produced by Pusa Chetki (11.05).

In case of, Shoot weight the highest mean Shoot weight per plant $(165.40 \mathrm{~g})$ was recorded in Miyasinge followed by Vedetar Local (127.15 g). Thelowest Shoot weight per plant $(50.50 \mathrm{~g})$ was recorded in Tokinasi variety.

Table 1. Growth parameters of different radish varieties at harvesting stages at Rampur, Chitwan, Nepal (2018)

\begin{tabular}{|l|c|c|c|}
\hline \multicolumn{1}{|c|}{ Varieties } & Plant height (cm) & Number of leaves per plant & Shoot weight per plant (g) \\
\hline Vedetar Local & $39.90^{\mathrm{ab}}$ & $20.25^{\mathrm{a}}$ & $127.15^{\mathrm{ab}}$ \\
\hline Miyasinge & $43.91^{\mathrm{a}}$ & $18.00^{\mathrm{ab}}$ & $165.40^{\mathrm{a}}$ \\
\hline Tokinasi & $43.69^{\mathrm{a}}$ & $18.85^{\mathrm{ab}}$ & $50.50^{\mathrm{c}}$ \\
\hline Pusa Chetki & $37.08^{\mathrm{b}}$ & $11.05^{\mathrm{c}}$ & $53.50^{\mathrm{c}}$ \\
\hline Mino Early Long White F1 & $39.56^{\mathrm{ab}}$ & $19.15^{\mathrm{ab}}$ & $79.50^{\mathrm{bc}}$ \\
\hline Ivory White F1 & $40.41^{\mathrm{ab}}$ & $15.85^{\mathrm{b}}$ & $71.80^{\mathrm{bc}}$ \\
\hline MAHY 22 F1 & $38.60^{\mathrm{ab}}$ & $20.54^{\mathrm{a}}$ & $81.90^{\mathrm{bc}}$ \\
\hline All Season & $42.73^{\mathrm{ab}}$ & $16.60^{\mathrm{ab}}$ & $79.70^{\mathrm{bc}}$ \\
\hline SEM \pm & 1.27 & 0.88 & 11.74 \\
\hline HSD $(0.05)$ & 6.0186 & 4.1819 & 55.7077 \\
\hline F-Test & $* *$ & $* *$ & 26.49 \\
\hline CV $(\%)$ & 6.23 & 10.05 & $* *$ \\
\hline
\end{tabular}

Means with same letter(s) within column do not differ significantly at $\mathrm{p}=0.05, \mathrm{SEM}=$ Standard error of means, HSD

$=$ Honest Significant Difference, $\mathrm{CV}=$ Coefficient of variance, $* *$ significant at $1 \%$ and $*$ significant at $5 \%$ level of significance

\section{Yield parameters}

The yield parameters of different varieties were found to be significantly different (Table 2). The highest mean value of Root length per plant $(19.51 \mathrm{~cm})$ was recorded in Ivory White F1 followed by Mino Early Long White F1 $(18.86 \mathrm{~cm})$ while, the lowest Root length per plant $(11.41 \mathrm{~cm})$ was found in Miyasinge at the time of harvesting.

The differences among the varieties on Root circumference at harvest was found significantly different. The highest mean Root circumference $(9.31 \mathrm{~cm})$ was recorded in Ivory White F1 followed by Mino Early Long White F1 $(9.15 \mathrm{~cm})$, which were at par with each other. Thelowest Root circumference $(7.72 \mathrm{~cm})$ was recorded in Vedetar Local variety.
The highest Root to shoot ratio per plant (1.29) was recorded in Ivory White F1. The lowest Root to shoot ratio per plant (0.33) was recorded in Miyasinge.

The highest mean Biomass yield at harvest (73.22t ha-1) was recorded in Miyasinge while, the lowest Biomass yield (29.77 $\mathrm{t} \mathrm{ha}^{-1}$ ) was recorded in Pusa Chetki.

The highest fresh Rootyield (30.87 $\left.\mathrm{tha}^{-1}\right)$ was produced by Ivory White F1 followed by hybrid variety Mino Early Long White F1 (23.35 $\left.\mathrm{t} \mathrm{ha}^{-1}\right)$ both being at par. Also, these were at par with MAHY 22 F1 (23.05 t $\left.\mathrm{ha}^{-1}\right)$. The lowest fresh Root yield $\left(11.93 \mathrm{t} \mathrm{ha}^{-1}\right)$ was recorded in Pusa Chetki. 
Table 2. Yield parameters of different radish varieties at harvesting stages at Rampur, Chitwan, Nepal (2018)

\begin{tabular}{|l|c|c|c|c|c|}
\hline \multicolumn{1}{|c|}{ Varieties } & $\begin{array}{c}\text { Root } \\
\text { length }(\mathbf{c m})\end{array}$ & $\begin{array}{c}\text { Root } \\
\text { circumference }(\mathbf{c m})\end{array}$ & $\begin{array}{c}\text { Root to } \\
\text { shoot ratio }\end{array}$ & $\begin{array}{c}\text { Total biomass } \\
\text { yield }\left(\mathbf{t ~ h a}^{-1}\right)\end{array}$ & $\begin{array}{c}\text { Root yield } \\
\left(\mathbf{t ~ h a}^{-1}\right)\end{array}$ \\
\hline Vedetar Local & $12.15^{\mathrm{cd}}$ & $7.72^{\mathrm{c}}$ & $0.40^{\mathrm{ab}}$ & $58.98^{\mathrm{a}}$ & $16.60^{\mathrm{b}}$ \\
\hline Miyasinge & $11.41^{\mathrm{d}}$ & $8.81^{\mathrm{ab}}$ & $0.33^{\mathrm{b}}$ & $73.22^{\mathrm{a}}$ & $18.08^{\mathrm{b}}$ \\
\hline Tokinasi & $14.76^{\mathrm{bcd}}$ & $8.51^{\mathrm{abc}}$ & $1.23^{\mathrm{ab}}$ & $32.50^{\mathrm{b}}$ & $15.67^{\mathrm{b}}$ \\
\hline Pusa Chetki & $15.60^{\mathrm{abc}}$ & $7.99^{\mathrm{bc}}$ & $0.67^{\mathrm{ab}}$ & $29.77^{\mathrm{b}}$ & $11.93^{\mathrm{b}}$ \\
\hline Mino Early Long White F1 & $18.86^{\mathrm{a}}$ & $9.15^{\mathrm{a}}$ & $0.89^{\mathrm{ab}}$ & $49.55^{\mathrm{ab}}$ & $23.35^{\mathrm{ab}}$ \\
\hline Ivory White F1 & $19.51^{\mathrm{a}}$ & $9.31^{\mathrm{a}}$ & $1.29^{\mathrm{a}}$ & $54.80^{\mathrm{ab}}$ & $30.87^{\mathrm{a}}$ \\
\hline MAHY 22 F1 & $17.66^{\mathrm{ab}}$ & $8.60^{\mathrm{abc}}$ & $0.87^{\mathrm{ab}}$ & $50.65^{\mathrm{ab}}$ & $23.05^{\mathrm{ab}}$ \\
\hline All Season & $16.34^{\mathrm{ab}}$ & $8.11^{\mathrm{bc}}$ & $0.85^{\mathrm{ab}}$ & $48.92^{\mathrm{ab}}$ & $22.05^{\mathrm{ab}}$ \\
\hline SEM \pm & 0.85 & 0.2239 & 0.27 & 5.56 & 3.45 \\
\hline HSD $(0.05)$ & 4.0488 & 1.062 & 0.90 & 26.36 & 11.58 \\
\hline F-Test & $* *$ & $* *$ & $*$ & $* *$ & $* *$ \\
\hline CV $(\%)$ & 10.81 & 5.26 & 26.65 & 22.32 & 24.12 \\
\hline
\end{tabular}

Means with same letter( $s$ ) within column do not differ significantly at $\mathrm{p}=0.05, \mathrm{SEM}=$ Standard error of means, HSD

$=$ Honest Significant Difference, $\mathrm{CV}=$ Coefficient of variance, $* *$ significant at $1 \%$ and $*$ significant at $5 \%$ level of significance

\section{Quality parameter}

The quality parameters of different varieties were found to besignificantly different (Table 3 ). The highest mean Root skin thickness $(0.27 \mathrm{~cm})$ was recorded in Miyasinge followed by Pusa Chetki $(0.21 \mathrm{~cm})$. The lowest Root skin thickness per plant $(0.15 \mathrm{~cm})$ was found in both Tokinasi and All Season.

The highest TSS content of root $\left(6.20^{\circ} \mathrm{Brix}\right)$ was recorded in variety Mino Early Long White F1 followed by hybrid varietyIvory White F1 (6.12 ${ }^{\circ}$ Brix) while, the lowest TSS content of root $\left(3.90^{\circ}\right.$ Brix $)$ was found in Tokinasi.
The highest content of Ascorbic acid (19.51 mg $100 \mathrm{~g}^{-1}$ ) was found inIvory White F1 followed by Mino Early Long White F1 (19.16 mg $100 \mathrm{~g}^{-1}$ ), which were at par with each other. The lowest(13.58 mg $\left.100 \mathrm{~g}^{-1}\right)$ was recorded in Vedetar Local.

The highest mean Dry matter percent of root (7.62\%) was recorded in Ivory White F1 followed by MAHY 22 F1(7.12\%)while the lowest Dry matter percent of root (4.75\%) was recorded in Pusa Chetki.

Table 3. Quality parameters of different radish varieties at harvesting stages at Rampur, Chitwan, Nepal (2018)

\begin{tabular}{|c|c|c|c|c|}
\hline Varieties & Skin thickness (cm) & TSS ( ${ }^{\circ}$ Brix) & $\begin{array}{l}\text { Ascorbic acid (mg } \\
\left.\qquad 100 \mathrm{~g}^{-1}\right)\end{array}$ & $\begin{array}{c}\text { Dry matter } \\
(\%)\end{array}$ \\
\hline Vedetar Local & $0.18^{a b}$ & $4.38^{\mathrm{cd}}$ & $13.58^{\mathrm{d}}$ & $6.63^{\mathrm{abc}}$ \\
\hline Miyasinge & $0.22^{\text {a }}$ & $4.33^{\mathrm{cd}}$ & $13.99^{\mathrm{d}}$ & $4.75^{\mathrm{d}}$ \\
\hline Tokinasi & $0.13^{b}$ & $3.90^{d}$ & $16.01^{\mathrm{c}}$ & $6.50^{\mathrm{bc}}$ \\
\hline Pusa Chetki & $0.21^{\mathrm{a}}$ & $4.72 \mathrm{bcd}$ & $18.35^{\mathrm{ab}}$ & $4.10^{d}$ \\
\hline Mino Early Long White F1 & $0.19^{\mathrm{ab}}$ & $6.20^{\mathrm{a}}$ & $19.16^{\mathrm{a}}$ & $6.62^{a b c}$ \\
\hline Ivory White F1 & $0.17^{\mathrm{ab}}$ & $6.12^{a b}$ & $19.51^{\mathrm{a}}$ & $7.62^{\mathrm{a}}$ \\
\hline MAHY 22 F1 & $0.15^{\mathrm{ab}}$ & $5.33 \mathrm{abc}$ & $17.39 \mathrm{bc}$ & $7.12^{\mathrm{ab}}$ \\
\hline
\end{tabular}




\begin{tabular}{|l|c|c|c|c|}
\hline \multicolumn{1}{|c|}{ Varieties } & Skin thickness (cm) & TSS $\left({ }^{\circ}\right.$ Brix) & $\begin{array}{c}\text { Ascorbic acid (mg } \\
\left.\mathbf{1 0 0} \mathbf{~ g}^{-1}\right)\end{array}$ & $\begin{array}{c}\text { Dry matter } \\
(\mathbf{\%})\end{array}$ \\
\hline All Season & $0.13^{\mathrm{b}}$ & $4.45^{\mathrm{cd}}$ & $16.30^{\mathrm{c}}$ & $6.00^{\mathrm{c}}$ \\
\hline SEM \pm & 0.015 & 0.3 & 0.3 & 0.22 \\
\hline HSD $(0.05)$ & 0.074 & 1.4156 & 1.46 & 1.05 \\
\hline F-Test & $* *$ & $* *$ & $* *$ & $* *$ \\
\hline CV $(\%)$ & 18.16 & 12.11 & 26.49 & 7.23 \\
\hline
\end{tabular}

Means with same letter(s) within column do not differ significantly at $\mathrm{p}=0.05, \mathrm{SEM}=$ Standard error of means, HSD $=$ Honest Significant Difference, $\mathrm{CV}=$ Coefficient of variance, ${ }^{* *}$ significant at $1 \%$ and $*$ significant at $5 \%$ level of significance

\section{Consumer acceptability:}

Consumer acceptability was measured on the basis of organoleptic evaluation based on size, shape, colour and taste. The cumulative record of all the characters were used to determine the consumers' acceptability. The result showed significant variation among the varieties. Ivory White F1 had the highest degree of acceptability (8.56) followed by Mino Early Long White F1 and MAHY22F1 (Figure 1).



Fig.1. Consumers' acceptability of radish varieties

\section{Discussion:}

Root shape and size, uniformity, color, texture and sensory quality are the important features for fresh market (Larsen \& Wold, 2016).Premature bolting is main problem of radish production in Terai region of Nepal during spring and summer. It leads to inadequate root formation and root becomes hardy, pithy and develop pungency before reaching the table size due to long day along with high temperature. Chetri and Wangdi (2019) suggested that shade net houses are suitable for warm area for growing vegetables during the summer season. It helps to improve yield as well as quality of the vegetables (Shahak et al., 2008).
Shade nets play a positive role on the quality and the development of phytochemical component of fresh vegetables (Ilic et al., 2018). Growth and yield characters such as plant height, number of leaves per plant, shoot weight, root to shot ratio, root length, root circumference and yield of radish are governed by genetic makeup of the varieties as well as growing environment.Radish cultivated in spring season produced more leaves than those of the autumn and winter season crop (Akoumianakis et al., 2011). Root length with appropriate circumference is the most important quality indicator for consumer acceptance. Root shape influences the market price of the product (Reid and English 2000).

Differences in yield among the cultivars may be due to genetic factors and their interaction with environmental factors. The variations in yield among these eight varieties (Table 2) may be due to varietal difference, as all these varieties are tested under same soil, management and similar agro-climatic conditions.

The significant variations in quality parameters were found from the evaluation of various radish varieties (Table 3). Mostly quantitative as well as qualitative traits are governed by the variation in genetic makeup of the individual variety but its degree is determined by complex interactions between environmental, genetic, and physiological factors (Kaneko, 2007; Tsuro, 2008). Highest content of Ascorbic acid,Dry matter percent of root and highest score from the consumer acceptability test was recorded in hybrid variety Ivory White F1 which performed better under shade net house for off season production at Chitwan condition. Highest TSS content was recorded in hybrid variety Mino Early Long White F1. The variety Ivory White F1 showed 
significantly superior growth, yield and quality attributes. Such differencesin TSS content in root of different radish varieties were also reported byPanwar et al. (2013), Dongarwar et al. (2017) and Priyanka et al. (2018). Likewise various researcher found variation in Root dry matter percent.Dhaliwal and Klair(2008) reported that maximum dry matter $(5.51 \%)$ was in variety Mino Early Long White. Dongarwar et al. (2018) reported maximum dry matter (6.9\%) in Arka Nishant variety. Mallikarjunarao et al. (2015) also reported maximum dry matter in Arka Nishant variety. The characteristic pungent flavor in radish is due to the presence of 4-methylthio-3-butenyl isothiocyanate (MTBITC). Consumer preferred the less pungent radish roots (Nakamura et al., 2008). The variations in skin thickness of root among different radish varieties might be due to genetic and/or environmental factors that affect the quality of the root. Higher concentrations of 4-methylthio-3-trans-butenyl isothiocyanate (MTBITC) werefound in the epidermal and subepidermal layers of the root which caused the pungency of the root (Cooganet al., 2001).

The experiment shows no premature bolting in any of the varieties during the whole growing period. In agreement with our findings, Rajasekar et al. (2014) found that cultivation of winter vegetables including radish, during summer season is possible through shade net house cultivation with higher yield and quality roots. Cheema et al. (2004) reported that cultivation of off-season vegetable crops under shade net can produce higher yield, advance the maturity and reduce the incidence of insect pest attack which is in line with the findings of present study.

\section{Conclusion:}

Premature bolting before formation of edible size root is the main problem for radish production in plains of Nepal during spring and summer. In this study, Ivory White F1 performed betteramong the tested varieties. Thus, this variety is suggested for cultivation in plain areas of Nepal during spring and summer season under net house condition. However, further studies are suggested to confirm this finding.

\section{Acknowledgement:}

The authors thankfully acknowledged the Nepal Agricultural Research Council, Kathmandu, Nepal for a research grant to conduct the experiment and Agriculture and Forestry University, Chitwan, Nepal for providing laboratory and other research facilities.

\section{Declaration of conflict of interest and ethical approval:}

K.M. Dahal involved in designing the experiment, laboratory work, data analysis and writing the manuscript. D.R. Bhattarai, M.D. Sharma and B. Poudel participated in designing the experiment, data analysis and writing the manuscript. All the authors have read the manuscript before submitting to the journal Nepalese Horticulture and declares that there is no any type of competing interest regarding the current manuscript. The current article does not include any human participants or animals by the authors and has taken prior approval if applicable.

\section{References:}

Akoumianakis, K. A., Karapanos, I. C., Giakoumaki, M., Alexopoulos, A. A., \& Passam, H. C. (2011). Nitrogen, season and cultivar affect radish growth, yield, sponginess and hollowness. DOI: https://doi.org/10.22069/IJPP.2012.725

Chandel, K. S., Pokharel, T. R., Chauhan, A., Sharma, J. K., \& Kataria, R. K. (2015). Genetic variability in biparental progenies of radish (Raphanus sativus L.). Himachal Journal of Agricultural Research, 41(2), 142-145.

Cheema, D. S., Kaur, P., \& Kaur, S. (2004). Off-season cultivation of tomato under net house conditions. In VII International Symposium on Protected Cultivation in Mild Winter Climates: Production, Pest Management and Global Competition 659 (pp. 177-181).

Chetri B. K., \& Wangdi D. (2019). Comparative analysis of growth parameters of protected organic leafy vegetables. Tropical Plant Research 6(3): 408416. DOI: https://doi.org/10.22271/tpr.2019. v6.i3.050

Coogan, R. C., Wills, R. B. H., \& Nguyen, V. Q. (2001). Pungency levels of white radish (Raphanus sativus L.) grown in different seasons in Australia. Food chemistry, 72(1), 1-3.

Dhaliwal, M. S., \& Klair, J. S. (2008). Sowing date affects development and root yield of radish. International journal of vegetable science, 13(3), 75-93. 
Dongarwar, L. N., Kashiwar, S. R., Ghawade, S. M., \& Dongarwar, U.R. (2018). Varietal Performance of Radish (Raphanus sativus L.) Varieties in Black Soils of Vidharbha-Maharashtra, India. Int. J. Curr. Microbiol. App. Sci, 7(1), 491-501. https:// doi.org/10.20546/ijcmas.2018.701.058

Dongarwar, L. N., Kashiwar, S. R., Ghawade, S. M., \& Dongarwar, U. R. (2017). Performance of Different Radish (Raphanus sativus L.) Varieties in Black Soils of VidharbhaMaharashtra. International Journal of Plant \& Soil Science. 20 (5): 1, 9.

Hamouda, A. M. A., Khalil, E. M. E. A., \& ElLeel, O. F. A. (2014). Evaluation of Some Introduced and Local Radish Varieties under Egyptian Conditions. Egyptian Journal of Horticulture, 41(1), 133-149.

Ilic, Z. S., Milenkovic, L., Sunic, L., \& Manojlovic, M. (2018). Color shade nets improve vegetables quality at harvest and maintain quality during storage. Contemporary Agriculture, 67(1), 9-19.

Jilani, M. S., Burki, T., \& Waseem, K. (2010). Effect of nitrogen on growth and yield of radish. J. Agric. Res, 48(2), 219-225.

Kaneko, Y., Kimizuka-Takagi, C., Bang, S. W., \& Matsuzawa, Y. (2007). Radish. In "Genome mapping and molecular breeding in plants, Vol. 5 Vegetables" Kole, C.

Kumar, R., Sharma, R., Gupta, R. K., \& Singh, M. (2012). Determination of genetic variability and divergence for root yield and quality characters in temperate radishes. International journal of vegetable science, 18(4), 307-318.

Larsen, H., \& Wold, A. B. (2016). Effect of modified atmosphere packaging on sensory quality, chemical parameters and shelf life of carrot roots (Daucus carota L.) stored at chilled and abusive temperatures. Postharvest Biology and Technology, 114, 76-85.

Lavanya, A. V. N., Sudhavani, V., Reddy, P. S., \& Chaitanya, K. (2014). Effect of sowing dates and spacing on growth and root yield of radish cv. pusa chetki. Plant archives, 14(1), 619-623.

Mallikarjunarao, K., Singh, P. K., Vaidya, A., Pradhan, R., \& Das, R. K. (2015). Genetic variability and selection parameters for different genotypes of radish (Raphanus sativus L.) under Kashmir valley. Ecology, Environment and
Conservation, 21(4), 361-364.

Mishra, G. P., Singh, N., Kumar, H., \& Singh, S. B. (2010). Protected Cultivation for Food and Nutritional Security at Ladakh. Defence Science Journal, 60(2).

MoALD. (2020). Statistical information on Nepalese Agriculture 2018/2019. Government of Nepal, Ministry of Agriculture and Livestock Development, Singhadurbar, Kathmandu, Nepal.

Nakamura, Y., Nakamura, K., Asai, Y., Wada, T., Tanaka, K., Matsuo, Okamoto, S., Meijer, J., Kitamura, Y., Nishikawa, A. \& Park, E. Y. (2008). Comparison of the glucosinolate myrosinase systems among daikon (Raphanus sativus, Japanese white radish) varieties. Journal of agricultural and food chemistry, 56(8), 27022707.

NARC. (2017). Annual report 2016/2017. Horticulture Research Division. Nepal Agricultural Research Council, Lalitpur, Nepal.

Nieuwhof, M. (1978). The effect of temperature on growth and development of cultivars of radish (Raphanus sativus L. var. radicula Pers.) under summer conditions. Netherlands Journal of Agricultural Science, 26(1), 68-75.

Noreen, Z., \& Ashraf, M. (2009). Changes in antioxidant enzymes and some key metabolites in some genetically diverse cultivars of radish (Raphanus sativus L.). Environmental and Experimental Botany, 67(2), 395-402. DOI: https://doi.org/10.1016/j.envexpbot.2009.05.011

Ola, A. L., Rana, D. K., \& Jhajhra, M. R. (2018). Evaluation of radish (Raphaanus sativus L) varieties under valley condition of Garhwal hills. Journal of Pharmacognosy and Phytochemistry, 7(1), 2740-2743.

Panwar, N. S., Mishra, A. C., Uniyal, S. P., Pandey, V., \& Bali, R. S. (2013). Effect of date of sowing on yield and quality of radish (Raphanus sativus L.) cultivars under rainfed mid-hill conditions of Uttarakhand. Annals of Agri Bio Research, 18(3), 360-363.

Politud, E. R. R. (2016). Growth and Yield Performance of Radish (Raphanus sativus L.) 'cv' Sow White'in Response to Varying Levels of Vermicast Applications. International Journal of Scientific and Research Publications, 6(5), 5357. 
Priyanka, M., Lakshmi, K. S., Reddy, P. S. S., Reddy, D. S., \& Krishna, S. M. B. (2018). Interaction Effect of Varieties and Sowing Dates on Growth and Quality of Radish in Southern Agro Climatic Zone of Andhra Pradesh. Int. J. Pure App. Biosci, 6(5), 227-231.

Rajasekar, M., Arumugam, T., Kumar, S. R., Balakrishnan, S., \& Krishnasamy, S. (2014). Screening vegetables under shadenet for yield and quality during summer and winter seasons.

Reid, J. B., \& English, J. M. (2000). Potential yield in carrots (Daucus carota L.): theory, test, and an application. Annals of Botany, 85(5), 593-605. DOI: https://doi.org/10.1006/anbo.2000.1108

Selvakumar, R. Singh, D. B., Sajad, U. N., Malik, G., Sharma, A. \& Gangadhara, K. (2019) Scientific Management of Pests and Diseases in Radish Cultivation. Indian farmer, 6(3): 198-202.

Shahak, Y., Ratner, K., Zur, N., Offir, Y., Matan, E., Yehezkel, H., ... \& Ben-Yakir, D. (2008). Photoselective netting: an emerging approach in protected agriculture. In International Symposium on Strategies Towards Sustainability of Protected Cultivation in Mild Winter Climate 807 (pp. 79-84). DOI:https://doi.org/10.17660/ ActaHortic.2009.807.7
Tey, Y. S., Mad Nasir, S., Zainalabidin, M., Jinap, S., \& Abdul Gariff, R. (2009). Demand for quality vegetables in Malaysia. International Food Research Journal, 16(3), 315-329.

Thorat, A. R., Kadam, A. S., \& Sarvade, S. A. (2015). "Performance of some improved and local varieties of radish (Raphanus sativus L.)". International Journal of Tropical Agriculture, 33(2 (Part I)), 503-506.

Tsuro, M., Suwabe, K., Kubo, N., Matsumoto, S., \& Hirai, M. (2008). Mapping of QTLs controlling root shape and red pigmentation in radish, Raphanus sativus L. Breeding Science, 58(1), 55-61. DOI:https://doi.org/10.1270/jsbbs.58.55 